\title{
Progression of fibrosing interstitial lung disease
}

\author{
Alyson W. Wong ${ }^{1,2}$, Christopher J. Ryerson ${ }^{1,2}$ and Sabina A. Guler ${ }^{3^{*}}$ (D)
}

\begin{abstract}
Fibrotic interstitial lung diseases (ILDs) are often challenging to diagnose and classify, but an accurate diagnosis has significant implications for both treatment and prognosis. A subset of patients with fibrotic ILD experience progressive deterioration in lung function, physical performance, and quality of life. Several risk factors for ILD progression have been reported, such as male sex, older age, lower baseline pulmonary function, and a radiological or pathological pattern of usual interstitial pneumonia. Morphological similarities, common underlying pathobiologic mechanisms, and the consistently progressive worsening of these patients support the concept of a progressive fibrosing (PF)-ILD phenotype that can be applied to a variety of ILD subtypes. The conventional approach has been to use antifibrotic medications in patients with idiopathic pulmonary fibrosis (IPF) and immunosuppressive medications in patients with other fibrotic ILD subtypes; however, recent clinical trials have suggested a favourable treatment response to antifibrotic therapy in a wider variety of fibrotic ILDs. This review summarizes the literature on the evaluation and management of patients with PF-ILD, and discusses questions relevant to applying recent clinicial trial findings to real-world practice.
\end{abstract}

Keywords: Interstitial lung disease, Pulmonary fibrosis, Progression, Outcomes, Disease classification, Pulmonary function tests

\section{Introduction}

Interstitial lung disease (ILD) is a heterogeneous group of diseases characterized by inflammation and fibrosis of the lung parenchyma [1]. An important subset of patients with fibrotic ILD experience a decline in lung function with progressive symptoms, poor response to treatment, and reduced quality of life. Idiopathic pulmonary fibrosis (IPF) is the most common, severe, and progressive subtype of idiopathic interstitial pneumonia [2]; however, other ILD subtypes also have a progressive fibrosing phenotype. These include connective tissue disease-associated ILD (CTD-ILD) [3-5], fibrotic hypersensitivity pneumonitis (HP), unclassifiable ILD, idiopathic non-specific interstitial pneumonia (NSIP), and rarely sarcoidosis, organizing pneumonia, and ILD associated with occupational exposures.

The current classification of ILD focuses on identifying the underlying etiology since this frequently impacts both

\footnotetext{
* Correspondence: sabina.guler@insel.ch

${ }^{3}$ Department of Pulmonary Medicine, Inselspital, Bern University Hospital,

University of Bern, Freiburgstrasse 18, 3010 Bern, Switzerland

Full list of author information is available at the end of the article
}

management decisions and prognostication $[1,6-9]$. The distinction between IPF and non-IPF ILDs is particularly important given the worse prognosis in IPF compared to other fibrosing ILDs [9], and the different approaches to pharmacotherapy. IPF is primarily a fibrotic ILD, while fibrosis in non-IPF ILDs is often preceded or associated with inflammation. These inflammatory pathways can lead to activation of fibroblasts and their differentiation into myofibroblasts, which produce extracellular matrix that perpetuates remodelling of healthy lung tissue to pulmonary fibrosis [10]. Despite important differences, distinct ILD subtypes often have overlapping morphological features and common pathological mechanisms, leading to the concept of a progressive fibrosing phenotype that can be applied to a variety of fibrotic ILDs [1]. Recent evidence has supported this concept by suggesting some shared biological mechanisms and greater overlap in treatment options compared to historical approaches [11-15].

In this review, we summarize the current literature on the disease behaviour, progression of fibrosing ILD other than IPF, and approaches to management of patients with fibrosing ILD and a progressive phenotype. We

(c) The Author(s). 2020 Open Access This article is distributed under the terms of the Creative Commons Attribution 4.0 International License (http://creativecommons.org/licenses/by/4.0/), which permits unrestricted use, distribution, and 
discuss the clinical utility of ILD classification according to disease behavior, potential definitions of progressive fibrosing ILD (PF-ILD), and challenges for clinical decision making in the context of emerging treatment possibilities in patients with PF-ILD.

\section{Definition of PF-ILD}

Patients with PF-ILD typically have self-perpetuating fibrosis characterized by worsening lung function, dyspnea, physical performance, and quality of life, as well as a poor response to therapy and early mortality [16]. Approximately $20-30 \%$ of patients with ILD are estimated to have PF-ILD [3-5]; however, there is no standardized definition of PF-ILD that clinicians and researchers have agreed upon. Several criteria have been used to define progression in patients with IPF, with most of these based on an absolute or relative decline in forced vital capacity (FVC) and diffusing capacity of the lung for carbon monoxide (DLCO) of $\geq 5-10 \%$ or $\geq 10-15 \%$ respectively, a decline in 6-min walk distance (6MWD) $>50 \mathrm{~m}$, or worsening dyspnea and quality of life scores [8, 17-20]. In patients with systemic sclerosis (SSc)-associated ILD (SSc-ILD), an absolute 1-year decline in FVC $\geq 10 \%$ or $5-9 \%$ plus a decline in DLCO $\geq 15 \%$ are strong predictors of mortality [21]. In RA-ILD, an absolute FVC decline of $\geq 10 \%$ has been used as evidence of progression based on the increased mortality in patients meeting this threshold [22].
Despite these associations in large cohort studies, FVC and DLCO trajectories can be unpredictable and are less reliable among individual patients given important intraand interpatient variability [4]. As a result, physicians typically use a combination of patient-reported symptoms, trends in pulmonary function tests, and the evolution of fibrosis on imaging (Fig. 1) to decide if there is clinically relevant ILD progression. Recently, several clinical trials have included patients with a progressive fibrosing phenotype, with the eligibility criteria for these studies helping to further guide a standardized definition of PF-ILD (Table 1) [14, 15, 25].

\section{Risk factors for progression}

Retrospective studies have identified risk factors that increase the likelihood of progression and mortality in PFILD including male sex, older age, lower FVC and DLCO at baseline, and certain morphological features $[3,6,9$, 21]. Specifically, a radiological and/or histological pattern of usual intersitial pneumonia (UIP) has been associated with increased mortality with poor prognosis also seen in patients with specific radiological features of UIP such as honeycombing and traction bronchiectasis [26-28]. The prognostic significance of a UIP pattern is seen across ILD subtypes, indicating that morphological pattern may be more prognostically important compared to the specific etiology of the disease $[9,29,30]$.

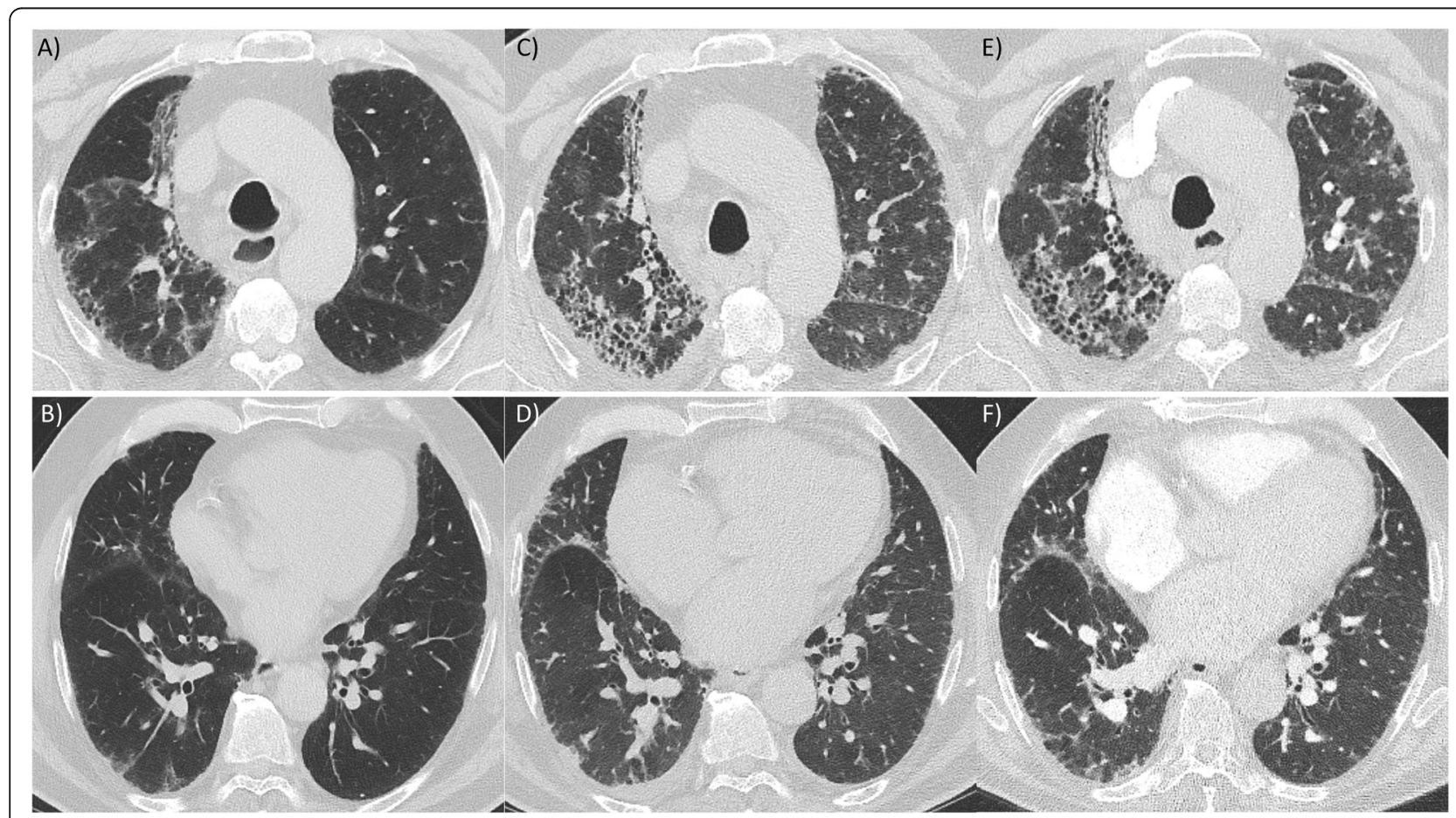

Fig. 1 Computed tomography imaging of the chest in a patient with progressive unclassifiable interstitial lung disease. Serial apical (a, $\mathbf{c}, \mathbf{e})$ and basal (b, d, f) axial images at baseline $(\mathbf{a}, \mathbf{b})$; at 36 months (c, d); and at 42 months $(\mathbf{e}, \mathbf{f})$. Images show upper lobe predominant pulmonary fibrosis with progressive reticulation, traction bronchiectasis, and honeycombing 
Table 1 Disease severity and definition of progression used in eligibility criteria for selected recently completed and ongoing clinical trials evaluating PF-ILD

\begin{tabular}{|c|c|c|c|c|c|c|}
\hline \multirow[t]{2}{*}{ Clinical trial } & \multicolumn{2}{|c|}{ Disease severity } & \multicolumn{4}{|c|}{ Minimum definition of progression } \\
\hline & $\begin{array}{l}\text { Pulmonary } \\
\text { function }\end{array}$ & $\mathrm{HRCT}$ & $\begin{array}{l}\text { Time } \\
\text { frame }\end{array}$ & Pulmonary function & Symptoms & $\mathrm{HRCT}$ \\
\hline $\begin{array}{l}\text { Pirfenidone in unclassifiable ILD } \\
\text { [15] }\end{array}$ & $\begin{array}{l}\text { FVC } \geq 45 \% \\
D L C O \geq 30 \% \\
6 M W D \geq \\
150 m\end{array}$ & $\begin{array}{l}\text { Fibrosis affecting }>10 \% \text { of } \\
\text { lung volume }\end{array}$ & $\begin{array}{l}6 \\
\text { months }\end{array}$ & $\begin{array}{l}\text { FVC }>5 \% \text { decline } \\
\text { (absolute) }\end{array}$ & $\begin{array}{l}\text { Worsening } \\
\text { symptoms }\end{array}$ & \\
\hline $\begin{array}{l}\text { Pirfenidone in progressive non-IPF } \\
\text { ILD (RELIEF) [23] }\end{array}$ & $\begin{array}{l}\text { FVC } 40-90 \% \\
\text { DLCO 25- } \\
75 \% \\
6 \mathrm{MWD} \geq \\
150 \mathrm{~m}\end{array}$ & & $\begin{array}{l}12 \\
\text { months }^{\mathrm{a}}\end{array}$ & $\begin{array}{l}\text { FVC } \geq 5 \% \text { decline } \\
\text { (absolute) }\end{array}$ & & \\
\hline \multirow[t]{3}{*}{$\begin{array}{l}\text { Nintedanib in non-IPF PF-ILD } \\
\text { (INBUILD) [14] }\end{array}$} & \multirow{3}{*}{$\begin{array}{l}\text { FVC } \geq 45 \% \\
\text { DLCO 30- } \\
80 \%\end{array}$} & \multirow[t]{3}{*}{$\begin{array}{l}\text { Fibrosis affecting }>10 \% \text { of } \\
\text { lung volume }\end{array}$} & \multirow[t]{3}{*}{$\begin{array}{l}24 \\
\text { months }\end{array}$} & $\begin{array}{l}\mathrm{FVC} \geq 10 \% \text { decline } \\
\text { (relative) }\end{array}$ & & \\
\hline & & & & At least two of: & & \\
\hline & & & & $\begin{array}{l}\text { FVC 5-10\% decline } \\
\text { (relative) }\end{array}$ & $\begin{array}{l}\text { Worsening } \\
\text { symptoms }\end{array}$ & $\begin{array}{l}\text { Increasing extent } \\
\text { of fibrosis }\end{array}$ \\
\hline $\begin{array}{l}\text { Pirfenidone in Patients With RA- } \\
\text { ILD (TRAIL1) [24] }\end{array}$ & $\begin{array}{l}\mathrm{FVC} \geq 40 \% \\
\mathrm{DLCO} \geq 30 \%\end{array}$ & $\begin{array}{l}\text { Fibrosis affecting }>10 \% \text { of } \\
\text { lung volume }\end{array}$ & $\begin{array}{l}12 \\
\text { months }\end{array}$ & $\begin{array}{l}\text { FVC } \geq 10 \% \text { decline } \\
\text { (relative) } \\
\text { or } \\
\text { FVC } 5-10 \% \text { decline } \\
\text { (relative) and } \\
\text { DLCO } \geq 15 \% \text { decline } \\
\text { (relative) }\end{array}$ & & \\
\hline
\end{tabular}

Abbreviations: DLCO diffusing capacity of the lungs for carbon monoxide, FVC forced vital capacity, HRCT high-resolution computed tomography, ILD interstitial lung disease, IPF idiopathic pulmonary fibrosis, PF-ILD progressive fibrosing ILD, RA rheumatoid arthritis, 6MWD 6-min walk distance

${ }^{a} \geq 3$ pulmonary function tests within 6-24 months, extrapolated to 12 months

An acute exacerbation is the most extreme type of ILD progression, characterized by a sudden and usually severe respiratory deterioration with new bilateral opacities on high-resolution computed tomography (HRCT) [31]. Risk factors for acute exacerbations in patients with IPF include severe dyspnea and low quality of life, higher body mass index, poor oxygenation, and low baseline FVC and DLCO. Patients with a recent relative decline in FVC $\geq 10 \%$ or DLCO $\geq 15 \%$ (hence PF-ILD by some definitions) are also more likely to experience an acute exacerbation [32-34]. Collectively, these findings suggest that patients with PF-ILD are at high risk for acute exacerbations. Recent studies have demonstrated the promise of specific blood biomarkers in predicting the risk of progression, acute exacerbations and mortality in patients with IPF and other PF-ILD, but additional prospective studies are needed to validate these findings and confirm their clinical utility $[35,36]$.

Similar to progression, mortality is challenging to predict for individual patients, in part related to the unpredictable occurrence of acute exacerbations and the high mortality from these events. The prognosis for patients with progressive ILD is worse than for stable and reversible ILD, although there is substantial variability across ILD subtypes even in patients with recent progression [37].
Most notably, patients with CTD-ILD and fibrotic HP appear to have a better prognosis than patients with IPF [9]. Additional data are needed to test whether this assumption of a worse prognosis in IPF remains valid when comparing to non-IPF patients who also have a progressive fibrotic phenotype.

\section{Management}

\section{Non-pharmacologic treatment}

The majority of non-pharmacological management strategies apply to all patients with fibrotic ILD, regardless of progression or the underlying etiology. Smoking cessation, antigen avoidance, protection from occupational exposures, and cessation of medications that can potentially cause ILD are all important. Pneumococcal vaccination and annual influenza vaccination are also appropriate in almost all patients with fibrotic ILD. With frequent loss of physical function and muscle mass in patients with severe and progressive ILD [38], pulmonary rehabilitation potentially relieves symptoms and improves exercise capacity [39]. Similarly, selected patients can benefit from long-term oxygen therapy [40]. Comorbidities and overall frailty can further reduce quality of life and survival, and patients are consequently likely to benefit from screening and management of important comorbidities [41, 42]. Early evaluation for lung 
transplant should be considered for patients with PFILD who are potentially eligible, while symptom-based management approaches including pallative care should take priority in patients with severe ILD who are not candidates for lung transplantation [43].

\section{Pharmacologic treatment}

Patients with PF-ILD have generally been treated with either antifibrotic therapy for IPF or immunosuppressive therapy for non-IPF ILD. The distinction between IPF and non-IPF ILD is particularly important because immunosuppressive therapy is harmful for patients with IPF [8], but potentially beneficial for patients with nonIPF ILD [44, 45]. For this reason, increasing diagnostic certainty within a multidisciplinary team discussion can help clinicians make more informed treatment recommendations, and this process can also inform management even in patients who are left without a confident diagnosis $[46,47]$.

\section{Antifibrotic therapy}

Pirfenidone and nintedanib are antifibrotic medications indicated for the treatment of IPF based on high-quality randomized placebo-controlled trials [18, 19, 48, 49]. Both medications attenuate migration, differentiation, and activation of fibroblasts, which are key cells in the development and progression of pulmonary fibrosis [50]. Preclinical studies suggest an antifibrotic effect in pulmonary fibrosis caused by a variety of different triggers. Both agents also have anti-inflammatory properties [51, 52]. The clinical trials that led to the approval of nintedanib and pirfenidone in IPF demonstrated approximately 50\% reduction in the rate of FVC decline in the treated group compared to placebo, with potential reduction in the risk of exacerbation and death $[18,19,49]$. Subgroup analyses from the pirfenidone and nintedanib clinical trials showed consistent treatment effects regardless of demographics and disease severity [53, 54]; and post-hoc analyses from nintedanib trials have further suggested potential efficacy in a broader population of patients with a multidisciplinary diagnosis of IPF who did not meet IPF diagnostic criteria from recent clinical practice guidelines [55].

The SENSCIS trial was the first phase III trial to investigate the efficacy and safety of nintedanib in patients with a non-IPF ILD [56], and based on this trial the U.S. Food and Drug Administration recently approved nintedanib for the treatment of SSc-ILD. Patients within 7 years of their first non-Raynaud SSc manifestation with at least $10 \%$ fibrosis on HRCT were included in the study. A stable background therapy with mycophenolate mofetil (MMF) was permitted, whereas patients with severe pulmonary hypertension or digital ulcers were excluded. Analysis of the primary outcome showed approximately $50 \%$ reduction in the rate of FVC decline in the treated group compared to placebo, but patients had overall less rapid progression compared to the IPF clinical trial populations [56]. There was no observed impact of treatment on Rodnan skin score or healthrelated quality of life. Tolerability of nintedanib was acceptable with a similar adverse effect profile compared to IPF patients. Diarrhea was the most frequent adverse effect, experienced by $76 \%$ of patients in the nintedanib and $32 \%$ of patients in the placebo group. The subgroup of patients receiving background MMF had less relative benefit from nintedanib compared to placebo (mean between-group difference $26 \mathrm{~mL} /$ year in patients on MMF versus $55 \mathrm{~mL} /$ year in patient without MMF).

An open-label phase 2 study showed acceptable adverse events profile of pirfenidone in patients with SScILD [57]. Tolerability of pirfenidone was similar to patients with IPF, with a slightly better tolerability when pirfenidone was titrated over 4 weeks instead of 2 weeks.

In addition to SSc-ILD, recently published clinical studies have investigated the effect of nintedanib and pirfenidone in patients with unclassifiable and other non-IPF PF-ILDs, with similar study designs compared to the previous IPF trials (Table 2). The INBUILD trial showed that annual FVC decline in PF-ILD patients receiving nintedanib was reduced by $57 \%(107 \mathrm{ml})$ compared to placebo, with more than $60 \%$ reduction in FVC decline $(128 \mathrm{ml})$ in patients who had a radiologic UIPlike pattern [14]. Patients in the INBUILD study were not permitted use of immunosuppressive medications, possibly suggesting a study population with less abundant inflammatory features. Several studies of pirfenidone have enrolled patients with a variety of non-IPF PF-ILD subtypes who have worsened despite therapy, including a study in unclassifiable ILD [15], and another study published only in abstract form that included patients with CTD-ILD, fibrotic idiopathic NSIP, fibrotic HP, and ILD associated with asbestosis [23]. In a recent phase 2 study evaluating pirfenidone in unclassifiable ILD, the safety profile of pirfenidone was reassuring with promising, but inconsistent efficacy signals that depended on both the endpoint and the method of statistical analysis. Specifically, FVC measured by daily home spirometry was chosen as the primary endpoint in this trial; however, these measurements were highly variable and prohibited performance of the planned statistical analysis. More reassuringly, results from spirometry performed at the study sites suggested a slower rate of FVC decline in patients on pirfenidone compared to placebo [15]. There are several ongoing studies that will further clarify the roles for nintedanib and pirfenidone in PF-ILD (Table 3). Regulatory bodies will soon make decisions on whether antifibrotic medications will receive indications for use in non-IPF ILDs. 
Table 2 Major randomized controlled trials investigating antifibrotic or immunosuppressive treatments in patients with non-IPF ILD

\begin{tabular}{|c|c|c|c|c|}
\hline Study & $\begin{array}{l}\text { Patient } \\
\text { population } \\
\text { (sample size) }\end{array}$ & Treatment $^{a}$ & $1^{\circ}$ endpoint & Selected $2^{\circ}$ endpoints \\
\hline
\end{tabular}

Antifibrotic medication

SENSCIS SSc-ILD (576) Nintedanib
(Phase 3) [56]
NCT02597933

NCT02597933

\begin{tabular}{|c|c|c|}
\hline $\begin{array}{l}\text { INBUILD } \\
\text { (Phase 3) [14] } \\
\text { NCT02999178 }\end{array}$ & $\begin{array}{l}\text { PF-ILD (663): } \\
\text { Fibrotic HP, } \\
\text { CTD-ILD, iNSIP, } \\
\text { unclassifiable } \\
\text { ILD }\end{array}$ & Nintedanib \\
\hline $\begin{array}{l}\text { LOTUSS } \\
\text { (Phase 2/ } \\
\text { Open-label) } \\
\text { [57] }\end{array}$ & SSc-ILD (63) & $\begin{array}{l}\text { Pirfenidone } \\
\text { (stable background } \\
\text { therapy with MMF } \\
\text { allowed) }\end{array}$ \\
\hline
\end{tabular}

\begin{tabular}{|c|c|}
\hline $\begin{array}{l}\text { RELIEF (Phase } \\
\text { 2) [23] } \\
\text { DRKS00009822 }\end{array}$ & $\begin{array}{l}\text { PF-ILD (127): } \\
\text { CTD-ILD, fibrotic } \\
\text { iNSIP, fibrotic } \\
\text { HP, asbestosis }\end{array}$ \\
\hline $\begin{array}{l}\text { Pirfenidone } \\
\text { in } \\
\text { unclassifiable } \\
\text { ILD (Phase 2) } \\
\text { [15] } \\
\text { CT03099187 }\end{array}$ & $\begin{array}{l}\text { Unclassifiable } \\
\text { PF-ILD (253) }\end{array}$ \\
\hline
\end{tabular}

Immunosuppressive medication

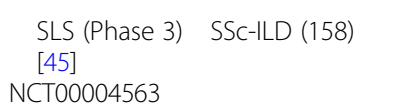

SLS II (Phase SSC-ILD (126)
3) [58]
NCT00883129

\begin{tabular}{|c|c|c|}
\hline FAST [59] & SSc-ILD (45) & $\begin{array}{l}6 \text { months of CYC i.v. } \\
\text { and prednisone } \\
\text { followed by } 6 \text { months } \\
\text { of AZA versus placebo }\end{array}$ \\
\hline $\begin{array}{l}\text { FOCUSSED } \\
\text { (Phase 3) } \\
\text { VCT02453256 }\end{array}$ & $\begin{array}{l}\text { SSC (210) } \\
\text { including SSC- } \\
\text { ILD (132) }\end{array}$ & Tocilizumab \\
\hline
\end{tabular}

[presented in

abstract form]

Pirfenidone (stable background therapy with MMF allowed)

CYC p.o.
Pirfenidone (added to Pirfenidone reduced the rate of FVC conventional therapy) decline over 48 weeks when statistical analyses used imputed data.

The prespecified analysis could not be performed due to high variability for individual daily home spirometry readings. decline over 52 weeks (mean betweengroup difference $107 \mathrm{~mL} ; 95 \% \mathrm{Cl}$ 65-149 $\mathrm{mL}, p<0.001$ ), with similar absolute benefit from nintedanib compared to IPF clinical trials.

An adverse event occurred in $97 \%$ of patients over 16 weeks. Patients in the 4 week titration group had improved tolerability compared to patients in the 2 week titration group. Tolerability was similar among patients on both MMF and pirfenidone compared to patients on pirfenidone only.

The
Nintedanib reduced the rate of FVC
decline over 52 weeks (mean betweenNo difference in mRSS and QOL. group difference $41 \mathrm{~mL} ; 95 \% \mathrm{Cl} 2.9-79 \mathrm{~mL}$,
$p=0.04$ ), with smaller absolute benefit from nintedanib compared to IPF clinical trials.

No difference in QOL and survival.

No difference in FVC, DLCO, patientreported outcomes or mRSS between the titration groups.

No difference in DLCO, 6MWD, QOL, and safety profile.

Pirfenidone reduced the rate of FVC decline over 24 weeks using site spirometry (mean between-group difference $95.3 \mathrm{~mL}, 95 \% \mathrm{Cl} 36-155 \mathrm{~mL}, p=0.002$ ). No differences in DLCO, 6MWD, and safety.

CYC reduced the rate of FVC decline over 52 weeks (mean between-group difference $2.53,95 \% \mathrm{Cl} 0.28-4.79 \%, p<0.03)$ after adjustment for baseline FVC.

MMF for 2 years versus No between-group difference in FVC over CYC p.o. for 1 year 24 months with a greater proportion of patients withdrawing from CYC than from MMF.

No between-group difference in FVC over 52 weeks in this small, potentially underpowered study.

No statistically significant difference in mRSS over 48 weeks (adjusted mean between-group difference $-1.73,95 \% \mathrm{Cl}$ $-3.78-0.32, p=0.098)$.
More adverse events in the CYC group.

No between-group difference in mRSS, change in HRCT lung fibrosis scores, or dyspnea score.

No between-group differences in HRCT fibrosis and dyspnea scores.

Tocilizumab reduced the rate of FVC decline over 48 weeks on post-hoc analysis in the subgroup of patients with SSc-ILD (mean between-group difference 6.4, 95\% Cl 3.3-9.4\%)

Abbreviations: $A Z A$ azathioprine, $C l$ confidence interval, $C T D$ connective tissue disease, $C Y C$ cyclophosphamide, DLCO diffusing capacity of the lungs for carbon monoxide, FVC forced vital capacity, HP hypersensitivity pneumonitis, HRCT high-resolution computed tomography, ILD interstitial lung disease, iNSIP idiopathic nonspecific interstitial pneumonia, IPF idiopathic pulmonary fibrosis, i.v. intravenous, MMF mycophenolate mofetil, mRSS modified Rodnan skin score, p.o. per os, QOL quality of life, SSc systemic sclerosis, 6MWD 6-min walk distance

${ }^{a}$ compared to placebo unless otherwise stated

\section{Immunosuppressive therapies}

Immunosuppressive medications are not appropriate in the chronic management of IPF given the increased risk of mortality and other adverse consequences, without any clear benefit [8]. Based on these findings, immunosuppressive medications are used with great caution in patients with an IPF-like phenotype. Conversely, these medications are generally considered appropriate in 
Table 3 Ongoing randomized controlled trials investigating antifibrotic and immunosuppressive treatments in non-IPF ILD

\begin{tabular}{|c|c|c|c|c|c|}
\hline Study & Patient population (sample size) & Treatment $^{\mathrm{a}}$ & $1^{\circ}$ endpoint & $\begin{array}{l}\text { Selected } 2^{\circ} \\
\text { endpoints }\end{array}$ & $\begin{array}{l}\text { Expected } \\
\text { completion } \\
\text { date }\end{array}$ \\
\hline \multicolumn{6}{|l|}{ Antifibrotic medications } \\
\hline $\begin{array}{l}\text { SLS III (Phase 2) } \\
\text { NCT03221257 }\end{array}$ & SSc-ILD (150) & $\begin{array}{l}\text { Pirfenidone (added to } \\
\text { MMF) }\end{array}$ & $\begin{array}{l}\text { Change in FVC over } 18 \\
\text { months }\end{array}$ & $\begin{array}{l}\text { Change in DLCO, } \\
\text { mRSS, QOL, } \\
\text { Dyspnea }\end{array}$ & $\begin{array}{l}\text { December } \\
2021\end{array}$ \\
\hline $\begin{array}{l}\text { Pirfenidone in SSc- } \\
\text { ILD (Phase 3) } \\
\text { NCT03856853 }\end{array}$ & SSC-ILD (144) & Pirfenidone & Change in FVC over 52 weeks & & $\begin{array}{l}\text { February } \\
2021\end{array}$ \\
\hline $\begin{array}{l}\text { TRAIL1 (Phase 2) } \\
\text { NCT02808871 }\end{array}$ & RA-ILD (270) & Pirfenidone & $\begin{array}{l}\text { Incidence of composite } \\
\text { endpoint of FVC decline } \\
\geq 10 \% \text { or death over } 52 \text { weeks }\end{array}$ & $\begin{array}{l}\text { Frequency of } \\
\text { progressive fibrosis } \\
\text { (FVC decline } \geq 10 \%, \\
\text { or } 5-10 \% \text { and DLCO } \\
\text { decline } \geq 15 \% \text { ) }\end{array}$ & $\begin{array}{l}\text { November } \\
2021\end{array}$ \\
\hline $\begin{array}{l}\text { PirFS } \\
\text { NCT03260556 }\end{array}$ & PF-sarcoidosis (60) & Pirfenidone & $\begin{array}{l}\text { Time to clinical worsening } \\
\text { over } 24 \text { months }\end{array}$ & $\begin{array}{l}\text { Change in FVC and } \\
\text { composite } \\
\text { physiologic index }\end{array}$ & $\begin{array}{l}\text { December } \\
2019\end{array}$ \\
\hline $\begin{array}{l}\text { Pirfenidone Fibrotic } \\
\text { HP NCT02958917 }\end{array}$ & Fibrotic HP (40) & Pirfenidone & Change in FVC over 52 weeks & $\begin{array}{l}\text { Progression-free } \\
\text { survival }^{b}\end{array}$ & $\begin{array}{l}\text { December } \\
2019\end{array}$ \\
\hline $\begin{array}{l}\text { Pirfenidone in DM- } \\
\text { ILD (Phase 3) } \\
\text { NCT03857854 }\end{array}$ & DM-ILD (152) & Pirfenidone & Change in FVC over 52 weeks & & $\begin{array}{l}\text { February } \\
2021\end{array}$ \\
\hline \multicolumn{6}{|c|}{ Immunosuppressive medications } \\
\hline $\begin{array}{l}\text { RECITAL (Phase 2- } \\
\text { 3) NCT01862926 }\end{array}$ & CTD-ILD (116) & Rituximab versus CYC & Change in FVC over 48 weeks & $\begin{array}{l}\text { Adverse events, } \\
\text { change in DLCO } \\
\text { and QOL }\end{array}$ & $\begin{array}{l}\text { November } \\
2020\end{array}$ \\
\hline $\begin{array}{l}\text { Bortezomib and } \\
\text { MMF in SSc-ILD } \\
\text { (Phase 2) } \\
\text { NCT02370693 }\end{array}$ & SSC-ILD (30) & $\begin{array}{l}\text { Bortezomib (added to } \\
\text { standard of care } \\
\text { immunosuppression) }\end{array}$ & Safety over 24 weeks & $\begin{array}{l}\text { Change in FVC, } \\
\text { mRSS, QOL }\end{array}$ & June 2020 \\
\hline $\begin{array}{l}\text { EvER-ILD (Phase 3) } \\
\text { NCT02990286 }\end{array}$ & $\begin{array}{l}\text { Idiopathic or CTD-associated NSIP } \\
\text { (non-responders to first-line im- } \\
\text { munosuppression) (122) }\end{array}$ & $\begin{array}{l}\text { Rituximab (added to } \\
\text { standard of care } \\
\text { immunosuppression) }\end{array}$ & $\begin{array}{l}\text { Change in FVC over } 6 \\
\text { months }\end{array}$ & $\begin{array}{l}\text { Change in 6MWD, } \\
\text { DLCO, dyspnea, } \\
\text { cough }\end{array}$ & June 2020 \\
\hline $\begin{array}{l}\text { ATtackMy-ILD } \\
\text { (Phase 2) } \\
\text { NCT03215927 }\end{array}$ & Myositis associated ILD (20) & $\begin{array}{l}\text { Abatacept (added to } \\
\text { standard of care } \\
\text { immunosuppression) }\end{array}$ & Change in FVC over 24 weeks & $\begin{array}{l}\text { Progression-free } \\
\text { survival }{ }^{c} \text { and } \\
\text { change in dyspnea }\end{array}$ & $\begin{array}{l}\text { December } \\
2020\end{array}$ \\
\hline
\end{tabular}

Abbreviations: CTD connective tissue disease, CYC cyclophosphamide, DLCO diffusing capacity of the lungs for carbon monoxide, DM dermatomyositis, FVC forced vital capacity, HP hypersensitivity pneumonitis, HRCT high-resolution computed tomography, ILD interstitial lung disease, MMF mycophenolate mofetil, $m R S S$ modified Rodnan skin score, NSIP idiopathic nonspecific interstitial pneumonia, QOL quality of life; SSc, systemic sclerosis, 6MWD 6-min walk distance ${ }^{a}$ compared to placebo unless otherwise stated

${ }^{b}$ time to FVC \%-predicted decline $\geq 5 \%$, or $6 \mathrm{MWD}$ decline $\geq 50 \mathrm{~m}$, or progression of fibrosis on HRCT, or acute exacerbation

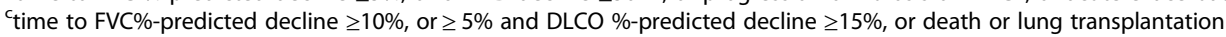

many patients with CTD-ILD or fibrotic HP, and in some patients with unclassifiable ILD (Table 2) [44].

Connective tissue disease-associated ILD Most evidence for the use of immunosuppressive medications in CTD-ILD is extrapolated from the Scleroderma Lung Study [45]. This study showed that patients receiving cyclophosphamide had a slower rate of FVC decline compared to placebo, with a mean absolute difference of $2.5 \%$ between groups after 1 year of therapy. However, concerns of toxicity, low tolerability, and loss of effect after 18 months led to the Scleroderma Lung Study II which compared 2 years of MMF to 1 year of oral cycphosphamide [58]. Although MMF and cyclophosphamide had similar efficacy, MMF had less hematotoxicity and substantially fewer premature study withdrawals. MMF is consequently the preferred initial and maintenance immunosuppressive agent for most patients with SSc-ILD [60]. Besides cyclophosphamide and MMF, other frequently used medications in CTD-ILD include azathioprine, methotrexate, and rituximab.

Tocilizumab is a subcutaneously administered interleukin 6 receptor- $\alpha$ inhibitor that was recently studied in phase II and III trials in patients with early and progressive SSc. The studies did not meet their primary endpoint, which was the difference in change of the modified Rodnan skin score between groups [57, 61]. Recent results from exploratory and post-hoc analyses 
revealed that fewer SSc-ILD patients in the tocilizumab group had a decline in FVC at 48 weeks, with quantitative lung fibrosis scores also supporting potential benefit from tocilizumab in this subgroup.

Fibrotic hypersensitivity pneumonitis Immunosuppressive medications are frequently used in patients with fibrotic HP despite the absence of prospective controlled trials. In patients with non-fibrotic HP, short courses of prednisone combined with exposure elimination may be sufficient to halt and even reverse the disease process. Management is more challenging in fibrotic HP, with many patients having a progressive fibrotic phenotype even with exposure elimination. Based on retrospective comparisons in patients with fibrotic HP, both MMF and azathioprine are well-tolerated, potentially reduce the need for prednisone, and may improve the trajectory of DLCO decline [44]. Despite the limited data, MMF and azathioprine are typically considered first-line options for patients with fibrotic $\mathrm{HP}$ who have had or are at risk of ongoing progression.

Unclassifiable ILD Approximately $12 \%$ of patients with ILD cannot be classified after a diagnostic workup, and management is particularly challenging in this patient population [62]. Unclassifiable ILD is a diverse collection of patients who frequently have features resembling CTD-ILD or fibrotic HP. The concept of a working diagnosis has been suggested as a useful approach in deciding upon the most appropriate management of these patients [46]. Depending on the relative likelihoods of different diagnoses in a patient with unclassifiable ILD, either antifibrotic or immunosuppressive therapy may be warranted. The use of immunosuppressive therapies in this situation is based on very limited retrospective data suggesting potential benefit from cyclophosphamide in the subgroup of unclassifiable ILD patients who have autoimmune features [63, 64].

Additional clinical trials are ongoing that might provide further evidence on the efficacy and safety of immunosuppressive therapies in patients with non-IPF ILDs (Table 3).

\section{Discussion}

The disease behaviour of various ILD subtypes has been studied in many observational cohorts and clinical trials, with many of these studies focusing on patients with a progressive fibrotic phenotype. The eligibility criteria of these studies have provided a starting point for the definition of PF-ILD [14, 15, 23, 24], with the clinical utility of this concept supported by the therapeutic benefits observed in some of these clinical trials $[14,15]$. Despite these significant advances, there are many uncertainties that still remain in the classification and management of PF-ILD.

\section{Is the concept of PF-ILD clinically useful?}

Establishing a confident ILD diagnosis is often challenging, with considerable heterogeneity in diagnoses assigned by different experienced multidisciplinary teams [47], and approximately $12 \%$ of patients remaining unclassifiable after a thorough evaluation including a surgical lung biopsy [62]. Although diagnostic certainty is often low in ILD, it is typically still feasible to characterize disease behaviour using symptoms or routine investigations such as pulmonary function tests and chest imaging.

There is therefore appeal to simply classifying patients with ILD based on previous or anticipated disease behaviour rather than needing to establish a confident diagnosis; however, there are also important disadvantages of this approach. First, this approach could detract from a thorough assessment for an underlying etiology, with the danger that crucial management steps such as antigen avoidance might be neglected, or that specific pharmacotherapy options may not be considered. Second, creation of such a large and heterogeneous cohort would complicate development and testing of targeted therapies that apply to specific subgroups. Finally, translation of clinical trial findings from a heterogenuous cohort to individual patients might be challenging, with limited ability to understand whether clinical trial results are being driven by a specific subset of patients.

Despite these concerns, recent clinical trials support the clinical utility of PF-ILD by demonstrating potential treatment implications of this designation $[14,15]$. It is therefore likely that the concept of PF-ILD will become further incorporated into clinical practice; however, with the important caveat that disease behaviour should be complementary to the current approach to ILD classification, rather than replacing it.

\section{How should PF-ILD be defined?}

There are no established diagnostic criteria available to determine disease progression or a definition of PF-ILD. Clinical trials have consistently defined PF-ILD based on worsening symptoms, pulmonary function, or imaging; however the specific combination of features and thresholds vary across studies (Table 1).

Decline in pulmonary function is a key criterion for PF-ILD in all studies, with a relative decline in FVC $\geq 10 \%$ being a common threshold for progression when used in isolation. Smaller changes in FVC (e.g. relative decline of $5-10 \%)$ are less specific [4, 65], and are typically complemented by worsening symptoms or imaging findings, which are often defined qualitatively. Most recent studies have not included DLCO in their definition of PF-ILD; however, previous studies and working group statements have proposed $\geq 15 \%$ decline in DLCO is clinically meaningful, 
with smaller changes often used in combination with other markers of ILD progression [20, 21].

Criteria for progression that are used in recent studies may not translate directly into a clinical setting. Notably, imaging studies are not feasible at all follow-up visits, and thus radiological progression will likely be a relatively infrequent criterion of disease progression in clinical practice. In addition, experienced clinicians frequently integrate these markers of progression in a more complex manner than what can feasibly be replicated in a clinical trial that prioritizes standardization. Finally, clinicians have many other markers of ILD progression to consider on an individual basis, including exercise capacity, oxygenation, and respiratory hospitalization. It is therefore likely that there will be some differences in how PF-ILD has been defined in clinical trials compared to how clinicians will define this subgroup in a real-world setting.

\section{How should clinicians choose between antifibrotic or immunosuppressive therapy in patients with non-IPF PF- ILD?}

Antifibrotic and immunosuppressive medications are both currently off-label for patients with non-IPF PFILD; however, recent data have generated interest in using these medications in some of these patients pending the necessary regulatory approvals.

In the future, potential management options for patients with PF-ILD will likely include no specific pharmacological treatment, immunosuppressive medication, antifibrotic medication, or a combination of these treatments.

The option to forgo initiation of both immunosuppressive and antifibrotic therapy will usually apply to patients with significant comorbidities, those who are likely to tolerate potential adverse effects poorly, patients in a palliative setting, and those who decline pharmacotherapy for other reasons. The choice between antifibrotic and immunosuppressive medication in PF-ILD has not been answered by recent clinical trials, as none of these studies have directly compared these two options [14, 15]. In the absence of robust head-to-head data, it will likely be most appropriate to consider antifibrotic medication in patients with an IPF-like phenotype, particularly those with a UIP pattern on chest imaging or lung biopsy, as well as patients for whom immunosuppression might be associated with greater potential adverse effects. Using immunsuppressive therapy as a firstline option is likely to be most beneficial in patients with a more inflammatory phenotype, and particularly those with an organising pneumonia pattern on chest imaging and other features of active autoimmunity $[63,64]$. There is a substantial "grey zone" of patients with fibrotic ILD who fall between these two extremes. Decisions in these patients will be more challenging, and should generally be supported by a multidisciplinary discussion as well as close communication with rheumatologists in patients with features of a CTD. In this situation, some clinicans use a brief trial (e.g., 1-2 months) of prednisone to identify potential candidates for longterm immunosuppression, prioritizing ongoing immunosuppression in patients who respond favourably to this shorter trial. The pragmatic assumption that short-term response to prednisone translates into long-term benefit of immunsuppressive medication needs to be established in controlled trials, and there is also the important downside that this approach is very likely harmful in patients with an underlying biology similar to IPF [8]. This approach should thus be used with caution. Lastly, the combination of antifibrotic and immunosuppressive medications is a potential option given that both therapies are targeting different biological pathways involved in the biology of non-IPF PF-ILD. Recent studies have shown that the combination of pirfenidone and MMF is safe in patients with unclassifiable ILD and similarly for nintedanib and MMF in SSc-ILD [15, 56].

Many questions remain to be answered in future studies of PF-ILD: Which antifibrotic and immunosuppressive therapies can be combined safely? What is the incremental benefit of these medications when added to an established background therapy? Should antifibrotics and immunosuppressants be combined upfront or sequentially only in the context of ongoing disease progression? How should response to these treatments be assessed? And how should the additional therapeutic burden be managed, particularly, in polymorbid and frail patients? Additional clinical trials are forthcoming that will provide further insight into these questions, as well as anticipated post-hoc analyses from recently published studies.

\section{Conclusion}

The term PF-ILD identifies a subgroup of patients with ILD who often have a poor prognosis, with recent clinical trials suggesting potential benefit from antifibrotic medication in this population. These trials support the utility of subclassifying patients with various fibrotic ILD subtypes based on their anticipated disease behaviour; however, it is critical to remember that this approach is complementary to establishing a confident clinical diagnosis that also carries important management and prognostic implications. Although recent advances have suggested exciting new options for patients with fibrotic ILD, many questions remain and collaborative efforts are needed to address these issues. 


\section{Abbreviations}

6MWD: 6-min walk distance; AZA: Azathioprine; Cl: Confidence interval; CTD: Connective tissue disease; CYC: Cyclophosphamide; DLCO: Diffusing capacity of the lungs for carbon monoxide; DM: Dermatomyositis;

FVC: Forced vital capacity; HP: Hypersensitivity pneumonitis; HRCT: Highresolution computed tomography; i.v.: Intravenous; ILD: Interstitial lung disease; IPF: Idiopathic pulmonary fibrosis; MMF: Mycophenolate mofetil; mRSS: Modified Rodnan skin score; NSIP: Nonspecific interstitial pneumonia; p.o.: Per Os; PF-ILD: Progressive fibrosing interstitial lung disease; QOL: Quality of life; RA: Rheumatoid arthritis; SSc: Systemic sclerosis; UIP: Usual interstitial pneumonia

\section{Acknowledgements}

We thank Alexander Pöllinger, Deptartment of Diagnostic, Interventional and Pediatric Radiology, Inselspital, Bern University Hospital and University of Bern, Switzerland, for the radiological images.

\section{Authors' contributions}

All authors contributed to writing and editing the manuscript, and approved the final version of the manuscript.

\section{Funding}

No funding was available for this review.

\section{Availability of data and materials}

Not applicable.

Ethics approval and consent to participate

Not applicable.

\section{Consent for publication}

Not applicable.

\section{Competing interests}

CJR reports grant funding and speaking fees from Boehringer Ingelheim and Hoffmann-La Roche. AWW and SAG report no competing interests relevant to this review.

\section{Author details}

${ }^{1}$ Department of Medicine, University of British Columbia, Vancouver, Canada. ${ }^{2}$ Centre for Heart Lung Innovation, University of British Columbia, Vancouver, Canada. ${ }^{3}$ Department of Pulmonary Medicine, Inselspital, Bern University Hospital, University of Bern, Freiburgstrasse 18, 3010 Bern, Switzerland.

\section{Received: 12 November 2019 Accepted: 15 January 2020}

\section{Published online: 29 January 2020}

\section{References}

1. Travis WD, Costabel U, Hansell DM, King TE Jr, Lynch DA, Nicholson AG, et al. An official American Thoracic Society/European Respiratory Society statement: update of the international multidisciplinary classification of the idiopathic interstitial pneumonias. Am J Respir Crit Care Med. 2013;188(6):733-48.

2. Ley B, Collard HR, King TE Jr. Clinical course and prediction of survival in idiopathic pulmonary fibrosis. Am J Respir Crit Care Med. 2011;183(4):431-40.

3. Zamora-Legoff JA, Krause ML, Crowson CS, Ryu JH, Matteson EL. Progressive decline of lung function in rheumatoid arthritis-associated interstitial lung disease. Arthritis Rheumatol. 2017:69(3):542-9.

4. Guler SA, Winstone TA, Murphy D, Hague C, Soon J, Sulaiman N, et al. Does systemic sclerosis-associated interstitial lung disease burn out? Specific phenotypes of disease progression. Ann Am Thorac Soc. 2018;15(12):1427-33.

5. Reiseter S, Gunnarsson R, Mogens Aalokken T, Lund MB, Mynarek G, Corander J, et al. Progression and mortality of interstitial lung disease in mixed connective tissue disease: a long-term observational nationwide cohort study. Rheumatology (Oxford). 2018;57(2):255-62.

6. Gimenez A, Storrer K, Kuranishi L, Soares MR, Ferreira RG, Pereira CAC. Change in FVC and survival in chronic fibrotic hypersensitivity pneumonitis. Thorax. 2018;73(4):391-2.
7. Fernandez Perez ER, Swigris JJ, Forssen AV, Tourin O, Solomon JJ, Huie TJ, et al. Identifying an inciting antigen is associated with improved survival in patients with chronic hypersensitivity pneumonitis. Chest. 2013;144(5):1644-51.

8. Raghu G, Anstrom KJ, King TE Jr, Lasky JA, Martinez FJ. Prednisone, azathioprine, and $\mathrm{N}$-acetylcysteine for pulmonary fibrosis. $\mathrm{N}$ Engl J Med. 2012;366(21):1968-77.

9. Ryerson CJ, Vittinghoff E, Ley B, Lee JS, Mooney JJ, Jones KD, et al. Predicting survival across chronic interstitial lung disease: the ILD-GAP model. Chest. 2014;145(4):723-8.

10. Varga J, Abraham D. Systemic sclerosis: a prototypic multisystem fibrotic disorder. J Clin Invest. 2007;117(3):557-67.

11. Juge PA, Lee JS, Ebstein E, Furukawa H, Dobrinskikh E, Gazal S, et al. MUC5B promoter variant and rheumatoid arthritis with interstitial lung disease. $\mathrm{N}$ Engl J Med. 2018;379(23):2209-19.

12. Ley B, Newton CA, Arnould I, Elicker BM, Henry TS, Vittinghoff E, et al. The MUC5B promoter polymorphism and telomere length in patients with chronic hypersensitivity pneumonitis: an observational cohort-control study. Lancet Respir Med. 2017;5(8):639-47.

13. Noth I, Zhang Y, Ma SF, Flores C, Barber M, Huang Y, et al. Genetic variants associated with idiopathic pulmonary fibrosis susceptibility and mortality: a genome-wide association study. Lancet Respir Med. 2013;1(4):309-17.

14. Flaherty KR, Wells AU, Cottin V, Devaraj A, Walsh SLF, Inoue Y, et al. Nintedanib in progressive Fibrosing interstitial lung diseases. N Engl J Med. 2019;381(18):1718-27

15. Maher TM, Corte TJ, Fischer A, Kreuter M, Lederer DJ, Molina-Molina M, et al. Pirfenidone in patients with unclassifiable progressive fibrosing interstitial lung disease: a double-blind, randomised, placebo-controlled, phase 2 trial. Lancet Respir Med. 2019. https://doi.org/10.1016/S2213-2600(19)30341-8.

16. Cottin V, Wollin L, Fischer A, Quaresma M, Stowasser S, Harari S. Fibrosing interstitial lung diseases: knowns and unknowns. Eur Respir Rev. 2019;28(151). https://doi.org/10.1183/16000617.0100-2018.

17. Zisman DA, Schwarz M, Anstrom KJ, Collard HR, Flaherty KR, Hunninghake GW. A controlled trial of sildenafil in advanced idiopathic pulmonary fibrosis. N Engl J Med. 2010;363(7):620-8.

18. Noble PW, Albera C, Bradford WZ, Costabel U, Glassberg MK, Kardatzke D, et al. Pirfenidone in patients with idiopathic pulmonary fibrosis (CAPACITY): two randomised trials. Lancet. 2011;377(9779):1760-9.

19. King TE Jr, Bradford WZ, Castro-Bernardini S, Fagan EA, Glaspole I, Glassberg MK, et al. A phase 3 trial of pirfenidone in patients with idiopathic pulmonary fibrosis. N Engl J Med. 2014;370(22):2083-92.

20. Khanna D, Mittoo S, Aggarwal R, Proudman SM, Dalbeth N, Matteson EL, et al. Connective tissue disease-associated interstitial lung diseases (CTD ILD) - report from OMERACT CTD-ILD working group. J Rheumatol. 2015:42(11):2168-71.

21. Goh NS, Hoyles RK, Denton CP, Hansell DM, Renzoni EA, Maher TM, et al. Short-term pulmonary function trends are predictive of mortality in interstitial lung disease associated with systemic sclerosis. Arthritis Rheumatol (Hoboken, NJ). 2017;69(8):1670-8.

22. Solomon JJ, Chung JH, Cosgrove GP, Demoruelle MK, Fernandez-Perez ER, Fischer A, et al. Predictors of mortality in rheumatoid arthritis-associated interstitial lung disease. Eur Respir J. 2016:47(2):588-96.

23. Guenther A, Prasse A, Kreuter M, Neuser P, Rabe K, Bonella F, et al. Late breaking abstract - exploring efficacy and safety of oral Pirfenidone for progressive, non-IPF lung fibrosis (RELIEF). Eur Respir J. 2019;54(suppl 63):RCT1879.

24. Solomon JJ, Danoff SK, Goldberg HJ, Woodhead F, Kolb M, Chambers DC et al. The design and rationale of the trail1 trial: a randomized double-blind phase 2 clinical trial of pirfenidone in rheumatoid arthritis-associated interstitial lung disease. Adv Ther. 2019;36(11):3279-87.

25. Cottin V, Hirani NA, Hotchkin DL, Nambiar AM, Ogura T, Otaola M, et al. Presentation, diagnosis and clinical course of the spectrum of progressivefibrosing interstitial lung diseases. Eur Respir Rev. 2018;35(6):1322-28 https:// doi.org/10.1183/16000617.0076-2018.

26. Flaherty KR, Thwaite EL, Kazerooni EA, Gross BH, Toews GB, Colby TV, et al. Radiological versus histological diagnosis in UIP and NSIP: survival implications. Thorax. 2003;58(2):143-8.

27. Kim EJ, Elicker BM, Maldonado F, Webb WR, Ryu JH, Van Uden JH, et al. Usual interstitial pneumonia in rheumatoid arthritis-associated interstitial lung disease. Eur Respir J. 2010;35(6):1322-8.

28. Oldham JM, Adegunsoye A, Valenzi E, Lee C, Witt L, Chen L, et al. Characterisation of patients with interstitial pneumonia with autoimmune features. Eur Respir J. 2016;47(6):1767-75. 
29. Goh NS, Desai SR, Veeraraghavan S, Hansell DM, Copley SJ, Maher TM, et al. Interstitial lung disease in systemic sclerosis: a simple staging system. Am J Respir Crit Care Med. 2008;177(11):1248-54.

30. Morisset J, Vittinghoff E, Lee BY, Tonelli R, Hu X, Elicker BM, et al. The performance of the GAP model in patients with rheumatoid arthritis associated interstitial lung disease. Respir Med. 2017;127:51-6.

31. Collard HR, Ryerson CJ, Corte TJ, Jenkins G, Kondoh Y, Lederer DJ, et al. Acute exacerbation of idiopathic pulmonary fibrosis. An international working group report. Am J Respir Crit Care Med. 2016;194(3):265-75.

32. Collard HR, Yow E, Richeldi L, Anstrom KJ, Glazer C. Suspected acute exacerbation of idiopathic pulmonary fibrosis as an outcome measure in clinical trials. Respir Res. 2013;14:73.

33. Kondoh Y, Taniguchi H, Katsuta T, Kataoka K, Kimura T, Nishiyama O, et al. Risk factors of acute exacerbation of idiopathic pulmonary fibrosis. Sarcoidosis Vasc Diffuse Lung Dis. 2010;27(2):103-10.

34. Song JW, Hong SB, Lim CM, Koh Y, Kim DS. Acute exacerbation of idiopathic pulmonary fibrosis: incidence, risk factors and outcome. Eur Respir J. 2011;37(2):356-63.

35. Alqalyoobi S, Adegunsoye A, Linderholm A, Hrusch C, Cutting C, Ma SF, et al. Circulating plasma biomarkers of progressive interstitial lung disease. Respir Med. 2014;108(7):1031-9. https://doi.org/10.1164/rccm.201907-1343LE.

36. Ohshimo S, Ishikawa N, Horimasu Y, Hattori N, Hirohashi N, Tanigawa K, et al. Baseline KL-6 predicts increased risk for acute exacerbation of idiopathic pulmonary fibrosis. Respir Med. 2014;108(7):1031-9.

37. Hyldgaard C, Bendstrup E, Wells AU, Hilberg O. Unclassifiable interstitial lung diseases: clinical characteristics and survival. Respirology. 2017; 22(3):494-500

38. Guler SA, Hur SA, Lear SA, Camp PG, Ryerson CJ. Body composition, muscle function, and physical performance in fibrotic interstitial lung disease: a prospective cohort study. Respir Res. 2019;20(1):56.

39. Dowman LM, McDonald CF, Hill CJ, Lee AL, Barker K, Boote C, et al. The evidence of benefits of exercise training in interstitial lung disease: a randomised controlled trial. Thorax. 2017;72(7):610-9.

40. Bell EC, Cox NS, Goh N, Glaspole I, Westall GP, Watson A, et al. Oxygen therapy for interstitial lung disease: a systematic review. Eur Respir Rev. 2017;26(143). https://doi.org/10.1183/13993003.00647-2019.

41. Guler SA, Kwan JM, Leung JM, Khalil N, Wilcox PG, Ryerson CJ. Functional aging in fibrotic interstitial lung disease: the impact of frailty on adverse health outcomes. Eur Respir J. 2019;53(3). https://doi.org/10.1183/13993003. 01587-2018.

42. Torrisi SE, Ley B, Kreuter M, Wijsenbeek M, Vittinghoff E, Collard HR, et al. The added value of comorbidities in predicting survival in idiopathic pulmonary fibrosis: a multicentre observational study. Eur Respir J. 2017; 5(12):968-80. https://doi.org/10.1016/S2213-2600(17)30383-1.

43. Kreuter M, Bendstrup E, Russell AM, Bajwah S, Lindell $K$, Adir $Y$, et al. Palliative care in interstitial lung disease: living well. Lancet Respir Med. 2017;5(12):968-80.

44. Morisset J, Johannson KA, Vittinghoff E, Aravena C, Elicker BM, Jones KD, et al. Use of mycophenolate mofetil or azathioprine for the management of chronic hypersensitivity pneumonitis. Chest. 2017;151(3):619-25.

45. Tashkin DP, Elashoff R, Clements PJ, Goldin J, Roth MD, Furst DE, et al. Cyclophosphamide versus placebo in scleroderma lung disease. N Engl J Med. 2006;354(25):2655-66.

46. Ryerson CJ, Corte TJ, Lee JS, Richeldi L, Walsh SLF, Myers JL, et al. A standardized diagnostic ontology for fibrotic interstitial lung disease. An international working group perspective. Am J Respir Crit Care Med. 2017; 196(10):1249-54

47. Walsh SLF, Wells AU, Desai SR, Poletti V, Piciucchi S, Dubini A, et al. Multicentre evaluation of multidisciplinary team meeting agreement on diagnosis in diffuse parenchymal lung disease: a case-cohort study. Lancet Respir Med. 2016:4(7):557-65.

48. Raghu G, Rochwerg B, Zhang Y, Garcia CA, Azuma A, Behr J, et al. An official ATS/ERS/JRS/ALAT clinical practice guideline: treatment of idiopathic pulmonary fibrosis. An update of the 2011 clinical practice guideline. Am J Respir Crit Care Med. 2015;192(2):e3-19.

49. Richeldi L, du Bois RM, Raghu G, Azuma A, Brown KK, Costabel U, et al. Efficacy and safety of nintedanib in idiopathic pulmonary fibrosis. N Engl J Med. 2014;370(22):2071-82

50. Wollin L, Wex E, Pautsch A, Schnapp G, Hostettler KE, Stowasser S, et al. Mode of action of nintedanib in the treatment of idiopathic pulmonary fibrosis. Eur Respir J. 2015;45(5):1434-45.
51. Wollin L, Distler JHW, Redente EF, Riches DWH, Stowasser S, SchlenkerHerceg $R$, et al. Potential of nintedanib in treatment of progressive fibrosing interstitial lung diseases. Eur Respir J. 2002;446(1-3):177-85. https://doi.org/ 10.1016/S0014-2999(02)01758-2.

52. Nakazato H, Oku H, Yamane S, Tsuruta Y, Suzuki R. A novel anti-fibrotic agent pirfenidone suppresses tumor necrosis factor-alpha at the translational level. Eur J Pharmacol. 2002;446(1-3):177-85.

53. Noble PW, Albera C, Bradford WZ, Costabel U, du Bois RM, Fagan EA, et al. Pirfenidone for idiopathic pulmonary fibrosis: analysis of pooled data from three multinational phase 3 trials. Eur Respir J. 2016;47(1):243-53.

54. Costabel U, Inoue Y, Richeldi L, Collard HR, Tschoepe I, Stowasser S, et al. Efficacy of Nintedanib in idiopathic pulmonary fibrosis across prespecified subgroups in INPULSIS. Am J Respir Crit Care Med. 2016;193(2):178-85.

55. Raghu G, Wells AU, Nicholson AG, Richeldi L, Flaherty KR, Le Maulf F, et al. Effect of Nintedanib in subgroups of idiopathic pulmonary fibrosis by diagnostic criteria. Am J Respir Crit Care Med. 2017;195(1):78-85.

56. Distler O, Highland KB, Gahlemann M, Azuma A, Fischer A, Mayes MD, et al. Nintedanib for systemic sclerosis-associated interstitial lung disease. N Engl J Med. 2019;380(26):2518-28.

57. Khanna D, Albera C, Fischer A, Khalidi N, Raghu G, Chung L, et al. An openlabel, phase II study of the safety and tolerability of Pirfenidone in patients with scleroderma-associated interstitial lung disease: the LOTUSS trial. J Rheumatol. 2016;43(9):1672-9.

58. Tashkin DP, Roth MD, Clements PJ, Furst DE, Khanna D, Kleerup EC, et al. Mycophenolate mofetil versus oral cyclophosphamide in sclerodermarelated interstitial lung disease (SLS II): a randomised controlled, doubleblind, parallel group trial. Lancet Respir Med. 2016;4(9):708-19.

59. Hoyles RK, Ellis RW, Wellsbury J, Lees B, Newlands P, Goh NS, et al. A multicenter, prospective, randomized, double-blind, placebo-controlled trial of corticosteroids and intravenous cyclophosphamide followed by oral azathioprine for the treatment of pulmonary fibrosis in scleroderma. Arthritis Rheum. 2006;54(12):3962-70.

60. Fernandez-Codina A, Walker KM, Pope JE. Treatment algorithms for systemic sclerosis according to experts. Arthritis Rheumatol (Hoboken, NJ). 2018; 70(11):1820-8.

61. Khanna D, Denton CP, Jahreis A, van Laar JM, Frech TM, Anderson ME, et al. Safety and efficacy of subcutaneous tocilizumab in adults with systemic sclerosis (faSScinate): a phase 2, randomised, controlled trial. Lancet. 2016; 387(10038):2630-40.

62. Guler SA, Ellison K, Algamdi M, Collard HR, Ryerson CJ. Heterogeneity in unclassifiable interstitial lung disease. A systematic review and metaanalysis. Ann Am Thorac Soc. 2018;15(7):854-63.

63. Fischer A, Antoniou KM, Brown KK, Cadranel J, Corte TJ, du Bois RM, et al. An official European Respiratory Society/American Thoracic Society research statement: interstitial pneumonia with autoimmune features. Eur Respir J. 2015:46(4):976-87.

64. Wiertz IA, van Moorsel CHM, Vorselaars ADM, Quanjel MJR, Grutters JC. Cyclophosphamide in steroid refractory unclassifiable idiopathic interstitial pneumonia and interstitial pneumonia with autoimmune features (IPAF) Adv Ther. 2019:36:3279-87. https://doi.org/10.1007/s12325-019-01086-2.

65. Le Gouellec N, Duhamel A, Perez T, Hachulla AL, Sobanski V, Faivre JB, et al. Predictors of lung function test severity and outcome in systemic sclerosisassociated interstitial lung disease. PLoS One. 2017;12(8):e0181692.

\section{Publisher's Note}

Springer Nature remains neutral with regard to jurisdictional claims in published maps and institutional affiliations.

\section{Ready to submit your research? Choose BMC and benefit from:}

- fast, convenient online submission

- thorough peer review by experienced researchers in your field

- rapid publication on acceptance

- support for research data, including large and complex data types

- gold Open Access which fosters wider collaboration and increased citations

- maximum visibility for your research: over $100 \mathrm{M}$ website views per year

At $\mathrm{BMC}$, research is always in progress.

Learn more biomedcentral.com/submission 